\title{
European Convention for the Protection of Human Rights and Fundamental Freedoms
}

\author{
William K. Coblentz* and Robert S. Warshaw**
}

[EDITORIAL Note: At this time when contimued attention is being directed to a review of the Charter of the United Nations, it is suggested that a proper review should include an examination of the indirect as well as the direct consequences of that body's deliberations. This article traces a development that took place both within and without the halls of the United Nations, the most recent event having occurred outside its framework. This article is especially interesting because it may provide an insight into a future role of the United Nations, appropriately to be considered when its Charter is reviewed.]

In reviewing the infancy of major social institutions, historians have of ten been struck by the paradox that what future generations have come to recognize as major stepping stones often pass unnoticed before the eyes of contemporaries. If paradoxes were predictions, a promising future would be assured for the development of an effective system of international guarantees of fundamental human rights. During a period when military and economic measures, such as the Marshall Plan, NATO, Benelux, the Schuman Plan, and the proposed European Army have absorbed the attention of imternationalists on both sides of the Atlantic, the Foreign Ministers of fifteen European nations, almost unnoticed, participated in an event which future historians may mark as a major landmark in the ageless struggle to protect the integrity of the individual against arbitrary state interference.

Meeting in Rome in November 4, 1950, the ministers, representing member states of the Council of Europe, ${ }^{1}$ signed a Convention for the Protection of Human Rights and Fundamental Freedoms, and on September 3, 1953 it went into effect. It took ratifications by ten states to accomplish this $^{2}$ for it was provided that it would come into force after the deposit of ten instruments of ratifications. ${ }^{3}$ The European Convention is unique in

* Member, San Francisco Bar.

* Member, New York Bar.

1 The Convention in its final form was signed in Rome on Noveunber 4, 1950 by Belgium, Denmark, France, West Germany, Iceland, Ireland, Italy, Luxembourg, Netherlands, Norway, Saar, Turkey, and the United Kingdom. It was subsequently signed by Greece and Sweden in Paris on November 28, 1950.

2 Art. 66 of Convention for Protection of Human Rights and Fundamental Freedoms, Documents, Councir of Europe, Consultative Assembly, Ordinary Sess., pt. III, Doc. No. 104, at 1028-45 (1950) as amended. This document is hereinafter referred to as CoNvENTION. Subsequently a Protocol to the Convention was adopted. Documents, Councri of Europe, Consultative Assembiy, 4th Ordinary Sess., pt. I, Appendix to Doc. No. 2, at 36-38 (1952).

3 The states are: United Kingdom, Norway, Sweden, German Federal Republic, Saar, Iceland, Ireland, Denmark, Greece, Luxeinbourg. 
that it constitutes the first agreement ever made in which national states have submitted human rights to a system of binding international legal controls.

The world has heard much of the United Nations Universal Declaration of Human Rights, adopted by the General Assembly on December 10, 1948. But while the Declaration remains just that, i.e., a declaration of principle, and while a United Nations Convention which was to implement the Declaration through enforcement machinery seems further than ever from enactment, ${ }^{4}$ the European Convention has carried the hopes expressed in the United Nations Convention into the sphere of action. Under such circumstances, it is all the more remarkable that it has been so uniformly neglected. The purpose of this article is to overcome that neglect by a summary of the background and the chief features of the European Convention together with what we hope are sonie analytical comments.

I

\section{BACKGROUND}

An examination of the background of the Convention reveals a unique cooperative effort by both private and public agencies on three different levels.

The initiative was supplied by a private orgamization, the European Movement, ${ }^{5}$ through detailed studies carried out by its legal committee composed of distinguished European jurists. ${ }^{6}$ In July of 1949 this committee produced a series of recommendations including a proposal for the creation of a European Court of Human Rights.

The Consultative Assembly of the Council of Europe ${ }^{7}$ undertook the second stage of the preparatory work. With the committee's recommendations before it, the Assembly debated the entire subject and at the conclusion of the arguments referred various proposals to its Conmittee on

4 On April 6, 1953 Secretary of State John Foster Dulles announced that the United States would not sign the proposed United Nations Convention.

5 This organization, established in October 1948 is a federation of six international organizations with national councils in fourteen countries and a central secretariat in Brussels. The coordinated efforts of the groups comprising the movement led to formation of the Council of Europe as well as the establishment of the Schuman Plan. The chairman of the movement is Paul-Henri Spaak, Belgian Foreign Minister.

6 This Committee was formed in May 1948 as a result of a proposal adopted by the European Moveinent for the maintenance of human rights; Pierre-Henri Tietgen, former French Minister of Justice, was its chairman. Sir David Maxwell-Fyfe, former British Attorney General and prosecutor at the Nuremberg trials, and Fernand Dehousse, former Belgian Senator and presently Professor of Law at Liege University, were rapporteurs.

7 Under the Statute of the Council of Europe the Consultative Assembly is the dehberative organ of the Council which has no powers of decision but makes recommendations to the Committee of Ministers which as the executive organ of the Council then acts on them as it sees fit. 
Legal and Administrative Questions. During the next few weeks this committee then drafted a report which was adopted by the Consultative Assembly on September 8, 1949.

The conmittee took as the basis of its work the Universal Declaration of Human Rights of the United Nations and enumerated ten rights which it proposed should be the subject of a guarantee.

Having set out these rights, the committee then considered the means by which this guarantee could be established. Member states might bring any alleged breach of the Convention before a Commission on Human Rights which would endeavor to settle the matter by conciliation. A similar right of petition was to be granted to private individuals or associations after exhausting local remedies. If conciliation failed the Commission itself or a member state might refer the matter to a proposed European Court of Justice, though private parties would have no such right. The Court would make decisions which would be transmitted to the Committee of Ministers of the Council of Europe with whom would rest responsibility for further action.

This plan thus proposed for the first time the institution of an effective remedy for the individual whose rights were infringed by a sovereign state. $\mathrm{He}$ would in his individual capacity have a direct recourse to an international organ, namely, the Commission, and though he could not himself appeal to the European Court, a state could be made answerable before the Court if the individual's case were championed by the Commission or by another signatory state.

The Committee of Ministers considered this recommendation of the Council of Europe at its meeting in November 1949 and decided to appoint a committee of governmental experts to prepare a draft convention which might serve as a basis for further discussion by the Committee of Ministers, due attention being paid to the progress achieved in this matter by the competent organs of the United Nations. In accordance with this decision a committee of governmental legal experts met in Strasbourg in February and March 1950 and proceeded to prepare a draft convention taking as the basis of its work the proposals of the Consultative Assembly.

While this committee made considerable progress in the preparation of a draft convention, it was unable to reach agreement on many questions. Among these was the problem of whether the rights to be protected should be merely enumerated, or defined in detail. The committee did not attempt to reach agreement on others, including the creation of a European court, which it considered to be of a political rather than legal character. It submitted to the Committee of Ministers a report containing a number of alternative texts. The ministers, after considering this report, decided to convene a meeting of senior officials of the various governments in order 
to make the political decisions necessary as a consequence of the report of the legal experts. This committee of senior officials met in Strasbourg in June 1950 and prepared a draft convention incorporating the greater part of the texts submitted by the legal experts. This draft adopted a compromise formula on the question of the enumeration or definition of human rights and proposed the creation of a European Court with optional jurisdiction. It left undecided a number of questions of largely political nature, such as the rights of individual petition which were referred to the ministers themselves for decision.

The Committee of Ministers during its fifth session considered the report of the senior officials together with the comments of the legal experts of the Consultative Assembly, and on August 7, 1950 they adopted a revised text of the draft convention. In this text the right of individual petition was made conditional on its acceptance by the government directly concerned and the jurisdiction of the court optional, not compulsory.

This revised text was then submitted to the Consultative Assembly at its Second Session, and again considered by the Assembly's legal committee. Its report was approved ${ }^{8}$ and considered by the Committee of Ministers meeting in Rome in November. Once more the ministers brought with them their legal advisers, who reviewed the aniendments proposed by the Assembly and undertook a final revision of the text. They were unable to reach unanimous agreement on accepting the majority of the amendments proposed by the Consultative Assembly, with the result that the convention was finally signed on November 4, 1950 substantially in the form in which it had been approved by the ministers in August.

II

\section{ANALYSIS OF THE CONVENTION}

The original proposals of the Consultative Assembly listed for inclusion in the European Convention ten rights from the Universal Declaration of the United Nations. These rights were: (1) Security of person; ${ }^{\circ}$ (2) Exemption from slavery and servitude; 10 (3) Freedom from arbitrary arrest, detention or exile; ${ }^{11}$ (4) Freedom from arbitrary interference in private and family hife, home, and correspondence; ${ }^{12}$ (5) Freedom of

8 Orders of the Dax, Minutes of Proceedings, Councri of Eurore, Consultative Assemisiy, 2d Sess., at 98 (1950). The final vote recorded 111 ayes from 111 representatives voting.

0 This corresponds to Articles 3,5 and 8 of the Universal Declaration of Human Rights, approved by the General Assembly of the United Nations, December 10, 1948. U.N. Doc. A/811, Dec. 16, 1948; 43 AMr. Jour. INT. LAw 127 (Supp. 1949). This document is hereinafter referred to as U.N. DECLARATION.

10 This corresponds to Article 4 of the U.N. Declaration.

11 This corresponds to Articles 9, 10 and 11 of the U.N. Decraration.

12 This corresponds to Article 12 of the U.N. Declaratron. 
thought, conscience, and religion; ${ }^{13}$ (6) Freedom of opinion and expression; ${ }^{14}$ (7) Freedom of assembly; ${ }^{15}$ (8) Freedom of association; ${ }^{10}$ (9) Freedom to unite in trade unions; ${ }^{17}$ (10) The right to marry and found a family. ${ }^{18}$

The first positive right histed in the United Nations Declaration states that "Everyone has the right to life, liberty and security of person." 10 The European Convention has, however, made the right to life the subject of a separate article. This right is set out in Article $I$ as the most fundamental of all; it is not limited merely to a general statement of principle, but provides specifically that "Everyone's right to life shall be protected by law." While this article was under discussion, some of the draftsmen proposed to incorporate the words of the first positive right of the UN Declaration in the draft convention. However, those who were exponents of the common law contended that a statement dealing with the "right to life" necessitated a statement of the circumstances in which someone legally may be deprived of his life-for example, in the execution of a sentence of court following conviction of a crime or when deprivation of life results from the use of force which is no more than absolutely necessary, in self defense. This resulted in the method of definition now found in Article 2 of the Convention.

The Assembly's list of ten separate rights taken from the thirteen different articles of the United Nations Declaration included as three separate rights: freedom of assembly, freedom of association, and freedom to unite in trade unions. It was found possible to combine all three in the convention and still enumerate and define them as well. ${ }^{20}$

The article dealing with freedom from slavery and servitude ${ }^{21}$ takes into account that any such guarantee needs to account for not only the old fashioned forms of enslavement of individuals, which are scarce today, but also the modern form of slavery or forced labor practiced by some totalitarian states. This is covered by the addition of a second paragraph to the effect that no one should be required to perform forced or compulsory labor. This provision in turn necessitated a careful definition of the circumstances in which compulsory labor is permissible in a democratic

13 This corresponds to Article 18 of the U.N. Declaration.

14 This corresponds to Article 19 of the U.N. Declakation.

15 This corresponds to Article 20 of the U.N. Declaration.

16 This corresponds to Article 20, paras. $i$ and ii of the U.N. Declaration.

17 This corresponds to Article 23, para. iv of the U.N. Declaration.

18 This corresponds to Article 16 of the U.N. DECIARATION.

19 Article 3, U. N. Declaration.

20 Article 11 of the CONvENTION reads: "Everyone has the right of freedom of peaceful assembly and to freedom of association with others, including the right to form and join trade unions for the protection of his interests."

21 Convention, art. 4. 
state; for example, military service and labor required of convicted criminals. ${ }^{22}$ While the right to life in the first article of the convention was based on the first half of the UN Declaration, Article 5 of the convention also incorporates the substance of Article 9 of the UN Declaration. ${ }^{23}$ It was agreed to incorporate the substance of this text in the European Convention; however, it necessitated defining the circumstances in which detention is lawful. This meant histing the following cases: detention after conviction by a competent court or for noncompliance with the lawful order of a court; arrest or detention to bring a suspect before a magistrate; detention of minors; detention of persons of unsound mind or suffering from infectious diseases. The result was to expand a phrase of two lines into nearly a page of printed text which constitutes Article 5 of the Convention.

In this way there was worked out a twentieth-century defimition of freedom which has been at the heart of the struggle for human rights through the centuries and in many different countries.

The Convention protects the individual against retroactive criminal laws. ${ }^{24}$ It provides that no one shall be held guilty of a criminal offense on account of any act which did not constitute an offense at the time it was committed. This represents an elententary principle of justice long recognized in most national systems of law. However, a modern addition has been made in another paragraph in this article relating to offenses under international law.

International law on this subject is not clearly defined, but the Nuremberg trials have established the principle that individuals may be held responsible before an international tribunal for acts which are criminal according to the general principles of law recognized by civilized nations. This principle applies even though such acts may not have been specifically defined as criminal by the law of any particular state at the time they were committed.

The Convention has been drafted to make it clear that the principles enunciated at Nuremburg are not inconsistent with the general protection against retroactivity contained in paragraph $1 .^{25}$

This method of detailed definition offers considerable advantages to those who will use and apply the Convention. It is possible through these definitions to have a much clearer idea of what rights it is intended to secure and of what limitations legitimately may be imposed on them, than is possible with the very general and therefore very vague enumeration in the United Nations Declaration. However, any attempt at exhaustive defi-

\footnotetext{
22 Convention, art. 4, para. 3.

23 Convention, art. 5.

24 Convention, art. 7.

25 Convention, art, 7, para. 2.
} 
nition always carries with it the danger of unintentional omissions which later may be construed as deliberate exclusions. Only the future will show if these pitfalls have been successfully avoided.

III

\section{THE EUROPEAN COMMISSION OF HUMAN RIGHTS}

The next task which fell to the drafters of the Convention was to devise machinery for the enforceinent of rights they had so carefully defined.

The Convention sets up an impartial Commission to which complaints can be made in the event of the failure of any member state to secure to anyone within its jurisdiction the rights and freedoms defined in the Convention. The members of the Commission are to be equal in number to the contracting parties and no two members can be nationals of the same state. The possibility of nationals of non-member states being appointed is not excluded.

The Commission's task is to investigate alleged breaches of the Convention-for which purpose the states concerned will furnish all necessary facilities-and to secure if possible a friendly settlement. The job of seeking a friendly settlement will be performed by a subcommittee of seven members, of whom each of the parties concerned may appoint one, while the remainder will be chosen by lot. If a friendly settlement is achieved, a brief report will be prepared and published. If the attempt to achieve a friendly settlement fails, the Commission as a whole is required to draw up a report and state its opinion as to whether the facts disclose a breach of its obligations by the state concerned. In order to encourage frank discussion and facilitate the search for truth, the Commission is to meet in camera and individual opinions may be stated in the report.

When settlement by negotiation fails, the Commission will forward its report to the Committee of Ministers, making such proposals as it thinks appropriate. ${ }^{26}$ The Convention allows for this procedure in view of the fact that not all the countries signing the Convention agreed as to the advisability of creating and recognizing a European Court of Human Rights.

If within a period of three months there is no referral to the Court of Human Rights, the Committee of Ministers must decide on the basis of the Commission's report whether a violation of the Convention has been committed and, if so, what measures shall be taken. The parties to the Convention regard as binding on them any decision of the Committee of Ministers in this respect. ${ }^{27}$

26 Conventron, art. 31.

27 It is of particular interest that such decisions of the Committee of Ministers are to be binding and taken by a two-thirds majority of the members entitled to sit on the Committee, since under articles 15 and 20 of the Statute of the Council of Europe the powers of the Com- 
IV

\section{TEIE RIGHT OF INDIVIDUAL PETITION}

Under Article 24 of the Convention any contracting state may refer to the Commission, through the Secretary General of the Council of Europe, any alleged breach of the provisions of the Convention by another contracting country. The value of this provision, however, is limited. In international agreements which regulate the conduct of states among themselves, it is, of course, highly desirable to provide for a tribunal before which one state can arraign another which has caused it imjury through noncompliance with the terms of the agreement. However, when the object of the agreement is to protect not states but individuals, the real party in imterest, if a breach of the agreement occurs, is the individual whose rights have been denied. It is, therefore, this individual who stands in need of a remedy, and the remedy that he needs is a right of appeal to a tribunal which is competent to call the offending party to account.

For these reasons the original proposals of the Consultative Assembly of Augnst 1949 included an individual right of petition to the Commission. This right was made subject, of course, to the stipulation that local remedies had been exhausted. The committee of legal experts added to the statement of the local remedies rule the words "according to the generally recognized rules of international law" in order to refer to the jurisprudence according to which improper delay by national tribunals is deemed to be an exhaustion of local remedies. During negotiations, however, a difference of opinion arose as to the desirability of including the right of individual petition, the fear being expressed that this right might easily lead to abuse, particularly in the interest of subversive propaganda. To guard against this danger express provisions were added to the effect that the Commission would not entertain petitions which were anonymous, manifestly illfounded, or an abuse of the right of petition. Nevertheless the objections to the right of individual petition were maintained. The legal committee of the Consultative Assembly emphasized that it was essential to preserve this right of individuals to seek a direct remedy. But the Committee of Ministers was unable to obtain unanimous agreement on this and decided as a compromise to make this right optional, namely, subject to an express declaration on the part of the government concerned that it recognize the competence of the Commission to receive petitions from mdividuals. After

mittee are only to make recommendations to governments and, for all important decisions of the Committee, the unanimous vote of those present and voting is required. It is the more significant that the Ministers have agreed to waive the unanimity rule when discharging their functions under the Convention of Human Rights, and that they have assumed in this sphere the power of making decisions. 
considerable dispute this was finally accepted, but it was provided that this would not go into effect until six contracting parties had accepted it. ${ }^{28}$

$\mathrm{V}$

\section{EUROPEAN COURT OF HUMAN RIGHTS}

The original proposals of the Consultative Assembly included the creation of a European Court of Human Rights to adjudicate infringements of the Convention which could not be settled by the Commission. A serious difference of opinion, however, arose on the basic question of whether a court should be created at all. The representatives of a number of countries were definitely opposed to the creation of a court on the ground that the needs of the Convention would be fulfilled by the Commission. Others, however, felt that only the creation of an impartial tribunal would be able to ensure the efficient protection of human rights. A compromise solution was sought which would involve the principle of optional jurisdiction. The court would have jurisdiction only in respect to those states which expressly accepted it. But then arose the further question whether the membership of the court and the burden of its expenditures should be limited to those states which made such declarations. It was finally decided to set up the European Court as an organ of the Council of Europe as a whole; all members would then participate in the election of the judges and in the expenses of the Court. At the same time the jurisdiction of the court would be optional and apply only to those states which accepted it. ${ }^{20}$

The decision to make the court an organ of all the member states led to the need of specifying the minimum number whose participation would be required to make it effective. It would be absurd to create a court if its jurisdiction would only be accepted by two or three. Finally, the figure was set at eight. Article 56 provides that no case can be brought before the court until a minimum of eight countries has accepted its jurisdiction; only then will the first election of judges be held.

The number of judges is restricted to the number of member countries of the Council of Europe. However, the cases are heard by a chamber of the court consisting of seven judges. The judge who is a national of a state which is party to the action will sit as a member of the chamber ex officio. In the case of a state which does not have a judge of its nationality on the court, a person of its choice shall sit in the capacity of judge. The names of the other judges are to be chosen by lot before the opening of each case.

28 To date, seven countries have recognized the right of individual petition: Iceland, Sweden, Denmark, Ireland, Belgium, Italy and Norway.

${ }^{29}$ Only Ireland, Denmark and the Netherlands have accepted the compulsory jurisdiction of the court. 
The judges serve for nine years ${ }^{30}$ and will be elected by the Consultative Assembly of the Council of Europe. ${ }^{31}$

VI

\section{APPLICATION TO OVERSEAS AND COLONIAL TERRITORIES}

A controversial issue during the course of negotiations over the Convention was the question whether it should apply to overseas and colonial territories of the countries concerned. One view held was that it should be so drafted as to apply automatically to such territories unless they were specifically excluded. The other view was that it should apply principally to metropolitan territories but be capable of extension to overseas territories by express declaration. The protagonists of the first view were anxious to secure as extensive an application of the Convention as possible and felt that the governments were less likely to exclude the colomial territories if such exclusion involved a public declaration. The advocates of the second view maintained that certain countries, especially the United Kingdom, could not constitutionally apply the Convention to their colonial territories without first consulting the colonial legislatures. Therefore, if extension to the colonies were automatic, it would not be possible for the governments of these countries to ratify the Convention before consulting a large number of separate legislatures to obtain their approval. Consequently, the practical result of the formula proposed would be to delay the ratification of the Convention by some of the principal signatories for such period as would be necessary for these consnltations to take place-which might mean a very considerable delay. After considerable discussion it was finally decided that there must be an express declaration before the Convention would apply to colonial territories.

\section{CONCLUSIONS}

While the European Convention on Human Rights is an imperfect document, it still represents an unprecedented step forward..$^{32}$ It constitutes a great advance over the Universal Declaration of Human Rights of the United Nations. While the latter amounts to nothing more than an expression of intentions, the Convention contains specific legal commitments which have been accepted by fifteen governments and which, as a result, should strengthen the cause of freedom throughout the world.

30 Convention, art. 40.

31 Convention, art. 39.

32 An additional step forward was made by the Consultative Assembly recommendation in the Protocol of 1952. Three additional rights were formulated: the right to own property, the right of parents to choose the education of their children, and the right to hold free elections. This Protocol has been ratified by the United Kingdom and Denmark. 
The most important innovations which it was hoped that the Convention would contain were two: the granting to individuals whose rights are denied of direct access to an international organ capable of protecting them; and the institution of a judicial body on the international plane competent to sit in judgment on national governments. Unfortunately, it was not politically possible to obtain immediate and unanimous agreement on the acceptance of the two provisions. Each of them remains optional in that they depend on an express supplementary declaration by the states concerned.

Nevertheless, a distinct advance has been made by the creation of the Commission to whose jurisdiction all signatory states are automatically subject at the instance of another contracting party; by the provision that the Committee of Ministers can make decisions by a two-thirds majority on reports of the Commission; and by the creation of the European Court of Human Rights, even with optional jurisdiction.

For these reasons the Convention can be welcomed as an important development, and few of those who took part in its preparation were under any illusions that it represented more than a first step. For in the words of the French Minister of Foreign Affairs, M. Schuman:

This Convention which we are signing is not as full or as precise as many of us would have wished. However, we have thought it our duty to subscribe to it as it stands. It provides foundations on which to base the defense of the human personality against all tyrannies and against all forms of totalitarianism. 